\title{
Autoantibodies Against the Purkinje Cell Protein RGS8 in Paraneoplastic Cerebellar Syndrome
}

\author{
Ramona Miske, PhD, Madeleine Scharf, PhD, Patrick Stark, Heiko Dietzel, MD, Corinna I. Bien, MD, \\ Christian Borchers, MD, Pawel Kermer, MD, Anthonina Ott, Yvonne Denno, Nadine Rochow, Kathrin Borowski, \\ Carsten Finke, MD, Bianca Teegen, PhD, Christian Probst, PhD, and Lars Komorowski, PhD
}

Neurol Neuroimmunol Neuroinflamm 2021;8:e987. doi:10.1212/NXI.0000000000000987

\section{Abstract}

\section{Objective}

To describe the identification of regulator of G-protein signaling 8 (RGS8) as an autoantibody target in patients with cerebellar syndrome associated with lymphoma.

\section{Methods}

Sera of 4 patients with a very similar unclassified reactivity against cerebellar Purkinje cells were used in antigen identification experiments. Immunoprecipitations with cerebellar lysates followed by mass spectrometry identified the autoantigen, which was verified by recombinant immunofluorescence assay, immunoblot, and ELISA with the recombinant protein.

\section{Results}

The sera and CSF of 4 patients stained the Purkinje cells and molecular layer of the cerebellum. RGS8 was identified as the target antigen in all 4 sera. In a neutralization experiment, recombinant human RGS8 was able to neutralize the autoantibodies' tissue reaction. Patient sera and CSF showed a specific reactivity against recombinant RGS8 in ELISA and immunoblot, whereas no such reactivity was detectable in the controls. Clinical data were available for 2 of the 4 patients, remarkably both presented with cerebellar syndrome accompanied by B-cell lymphoma of the stomach (patient 1, 53 years) or Hodgkin lymphoma (patient 2, 74 years).

\section{Conclusion}

Our results indicate that autoantibodies against the intracellular Purkinje cell protein RGS8 represent new markers for paraneoplastic cerebellar syndrome associated with lymphoma.

\section{Classification of Evidence}

This study provided Class IV evidence that autoantibodies against the intracellular Purkinje cell protein RGS8 are associated with paraneoplastic cerebellar syndrome in lymphoma.

\author{
Correspondence \\ Dr. Miske \\ r.miske@euroimmun.de
}

\section{MORE ONLINE}

\section{$\rightarrow$ Class of Evidence \\ Criteria for rating therapeutic and diagnostic studies \\ NPub.org/coe}




\section{Glossary}

DNER = delta and notch-like epidermal growth factor-related receptor; HEK = human embryonic kidney; IFA = immunofluorescence assay; IVIG = intravenous immunoglobulin; LSM = laser scanning microscope; MALDI-TOF = matrixassisted laser desorption/ionization-time of flight mass spectrometry; PBS = phosphate-buffered saline; PMF = peptide mass fingerprinting; PNS = Paraneoplastic neurologic syndrome; POD = peroxidase; RC-IFA = recombinant immunofluorescence assay; RGS8 = regulator of G-protein signaling 8; SDS-PAGE = sodium dodecyl sulfate polyacrylamide gel electrophoresis; TMB = tetramethyl benzidine.

Paraneoplastic neurologic syndromes (PNSs) present a heterogeneous group of immune-mediated neurologic disorders that are associated with a tumor outside the brain. ${ }^{1,2}$ PNS can affect different neurologic structures including the cerebellum, brainstem, or the limbic system, causing a variety of neuronal symptoms. Serologic analyses of PNS patient sera often reveal autoantibodies against intracellular or cell surface expressed neuronal proteins. Anti-Hu, anti-Yo, anti$\mathrm{Ri}$, anti-CV2, anti-Ma2, anti-amphiphysin, and anti-SOX1 autoantibodies belong to the classical PNS-associated autoantibodies that bind to intracellular target antigens expressed in the cerebellum. Antibodies to intracellular antigens were shown to be not pathogenic. ${ }^{3}$ However, they serve as useful markers for PNS diagnosis in clinical practice. Their detection can support early recognition of cancer because neurologic symptoms frequently precede tumor discovery for month or years. The tumors most commonly found in patients with PNS are small-cell lung cancer, breast cancer, ovarian cancer, lymphoma, thymoma, or seminoma. In some cases, it was shown that the neuronal antigens are also expressed by the underlying tumor. ${ }^{4}$ The current hypothesis is that an immune response against tumor cell antigens could lead to a misdirected autoimmune reactivity against the nervous system expressing the same proteins. It is believed that the immune response is mediated by cytotoxic $\mathrm{T}$ cells leading to the loss of neurons. This might be the reason why patients with PNS usually respond poorly to autoantibody removal therapies.

Lymphomas are very rarely found in patients with PNS and usually do not associate with any known autoantibody. ${ }^{5}$ Few exceptions so far are represented by patients with Hodgkin lymphoma and cerebellar syndromes or limbic encephalitis, which may harbor anti-Tr (delta and notch-like epidermal growth factor-related receptor [DNER]), anti-mGluR5, or antimGluR1 autoantibodies..$^{6-9}$ In this study, we describe a novel cytoplasmic neuronal target antigen in 2 patients with cerebellar syndrome associated with Hodgkin lymphoma or B-cell lymphoma of the stomach.

\section{Methods}

Our primary research question was the identification of the target antigen of patient sera with similar autoantibody reactivities in indirect immunofluorescence assay (IFA) on cerebellar cryosections.

\section{Patients}

The patients were diagnosed and treated at the departments of neurology of the contributing hospitals. The Clinical Immunological Laboratory Stöcker, Lübeck (Germany), received the serum samples for the purpose of autoantibody testing. Subsequently, they were anonymized and provided to the authors.

Control panels included sera of 152 healthy donors and CSF of 20 patients with neurologic symptoms but without IFA reactivity on cerebellar sections. Additional control panels consisted of 350 samples from patients with tumor, encompassing 66 sera from patients with lung cancer, 10 sera from patients with cervical cancer, 83 sera from patients with breast cancer, 8 sera from patients with ovarian cancer, 26 sera from patients with prostate cancer, 24 from patients with Hodgkin lymphoma, and 133 from patients with non-Hodgkin lymphoma.

\section{Standard Protocol Approvals, Registrations, and Patient Consents}

Written informed consent to the publication of all clinical information was obtained from all patients of whom clinical data are reported in this study. An approval from the relevant ethical committee was received (Charité Berlin, EA1/ 222/16).

\section{Indirect Immunofluorescence Assay}

IFA was performed using slides with a biochip mosaic of brain tissue cryosections (cerebellum of the rat and monkey and sagittal sections of the murine whole brain) in addition to recombinant human embryonic kidney (HEK)293 cells separately expressing 30 different neuronal antigens. Each biochip array was incubated with serum or CSF diluted in phosphate-buffered saline (PBS) for 30 minutes, washed with PBS-Tween, and immersed in PBS-Tween for 5 minutes. Subsequently, either fluorescein isothiocyanate-labeled goat anti-human IgG (EUROIMMUN Medizinische Labordiagnostika AG, Luebeck, Germany) or Alexa488-labeled goat anti-human IgG (1:500, Jackson Research, Suffolk, United Kingdom) was applied for 30 minutes. After another washing step with PBS-Tween, and embedding the slides in PBSbuffered 1,4-diazabicyclo[2.2.2] octane-containing glycerol, they were analyzed by fluorescence microscopy. Based on the fluorescence intensity of the transfected cells in direct comparison with nontransfected cells and control samples, reactivities were classified as positive or negative. End point titers refer to the last dilution showing visible fluorescence. 
Cell nuclei were visualized by DNA staining with TO-PRO-3 iodide (1:2,000, Thermo Fisher Scientific, Dreieich, Germany) or 4',6-diamidino-2-phenylindole (DAPI) $(0.067 \mu \mathrm{g} / \mathrm{mL}$, Sigma-Aldrich, Heidelberg, Germany). In competitive inhibition experiments, sera diluted 1:32 in PBS-Tween were preincubated for 1 hour with recombinant regulator of G-protein signaling 8 (RGS8) expressing HEK293 cell lysate or as control empty vector transfected HEK293 cell lysate diluted 1:10 in PBS-Tween, before they were incubated in an IFA on cerebellar tissue sections. Results were evaluated by 2 independent observers using laser scanning microscopes (LSM700 or LSM880, Zeiss, Jena, Germany). To generate pictures of whole-brain sections, different partial scans were combined. All incubation steps were performed at room temperature.

\section{Immunoprecipitation}

The shock-frozen rat cerebellum was homogenized in solubilization buffer $(100 \mathrm{mmol} / \mathrm{L}$ tris- $\mathrm{HCl} \mathrm{pH} 7.4,150 \mathrm{mmol} / \mathrm{L}$ sodium chloride, $2.5 \mathrm{mmol} / \mathrm{L}$ ethylenediaminetetraacetic acid, $0.5 \%$ (wt/vol) sodium deoxycholate, $1 \%$ (wt/vol) Triton X-100 including protease inhibitors (Complete mini, Roche Diagnostics, Penzberg, Germany) with a Miccra D-8 (Roth, Karlsruhe, Germany) and a hand homogenizer (Sartorius, Göttingen, Germany) at $4^{\circ} \mathrm{C}$. After the lysate was centrifuged at $21,000 \mathrm{~g}$ at $4^{\circ} \mathrm{C}$ for 15 minutes, the supernatant was incubated with patient or control sera (diluted $1: 16.7$ ) at $4^{\circ} \mathrm{C}$ overnight, followed by an incubation with Protein G Dynabeads (Thermo Fisher Scientific, Dreieich, Germany) at $4^{\circ} \mathrm{C}$ for 3 hours. Beads were washed 3 times with PBS and eluted with NuPage lithium dodecyl sulfate sample buffer (Thermo Fisher Scientific, Schwerte, Germany) containing $25 \mathrm{mmol} / \mathrm{L}$ dithiothreitol at $70^{\circ} \mathrm{C}$ for 10 minutes. Before sodium dodecyl sulfate polyacrylamide gel electrophoresis (SDS-PAGE; NuPAGE, Thermo Fisher Scientific, Schwerte, Germany), carbamidomethylation with $59 \mathrm{mM}$ iodoacetamide (Bio-Rad, Hamburg, Germany) was performed. Separated proteins were visualized with Coomassie Brilliant Blue (G-250) (Merck) gel staining and identified by mass spectrometric analysis.

\section{Mass Spectrometry}

This method was described in detail in Scharf et $\mathrm{al}^{10} 2018$. Briefly, protein bands were excised from Coomassie Brilliant Blue G-250 stained gels, destained, and tryptic digested. Peptides were extracted, spotted onto an MTP AnchorChip 384 BC target, and analyzed by matrix-assisted laser desorption/ionization-time of flight mass spectrometry (MALDI-TOF)/TOF mass spectrometry with an AutoFlex III smartbeam TOF/TOF200. MS spectra for peptide mass fingerprinting (PMF) were recorded in a mass range from 600 Da to 4,000 Da, processed with flexAnalysis 3.0, 3.3, or 3.4, and peak lists were analyzed with BioTools 3.2 using the Mascot search engine Mascot Server 2.3 (Matrix Science, London, United Kingdom) for protein identification with a significance threshold of $p<0.05$. For further confirmation of the PMF hits, 2 to 5 peptides of each identified protein were selected for MS/ MS measurements.

\section{Construction of Recombinant Vectors Encoding RGS8 or RGS8-His}

The coding DNA for human RGS8 (UNIPROT acc. \#P57771) was obtained by PCR on commercially available cDNA (IRATp970H06133D, Source BioScience, Nottingham, UK) and primers ATACGTCTCACATGGCGGCCTTACTGAT GCCACGC (sense RGS8) and ATACGTCTCCTCGAGACTGAGCCTCCTCTGGCTTTGGGAC (asense RGS8) or ATACGTCTCCTCGAGCTAACTGAGCCTCCTCTGGCT TTGG (asense RGS8-Stop). The amplification products were digested with Esp3I and DpnI and ligated with pTriEx-1 (Merck, Darmstadt, Germany) or pET24d-N as described above. ${ }^{11}$

\section{Recombinant Expression of RGS8 in HEK293}

RGS8 (dHis) was expressed in human HEK293 cells after ExGen500-mediated transfection (Thermo Fisher Scientific, Schwerte, Germany) according to the manufacturer's instructions. To prepare substrates for IFA, HEK293 cells were seeded on sterile cover glasses, transfected, and allowed to express RGS8 for 48 hours. Cover glasses were washed with PBS, fixed with acetone for 10 minutes at room temperature, air dried, cut into millimeter-sized biochips, and used as substrates in IFA as described. Alternatively, cells were transfected in standard T-flasks and harvested after 5 days. The cell sediment was extracted with solubilization buffer (12.5 Mio cells $/ \mathrm{mL})$. The extracts were stored in aliquots at $-80^{\circ} \mathrm{C}$ until further use.

\section{Recombinant Expression of RGS8-His in Escherichia coli and Purification}

RGS8-His was expressed in E coli RosettaBlue (DE3)pLacI (Merck, Germany) as described previously. ${ }^{11}$ For protein purification, bacterial sediments were resuspended in $50 \mathrm{mM}$ TRIS-HCl pH 8.0, $0.3 \mathrm{M} \mathrm{NaCl}, 1 \mathrm{mM}$ phenylmethylsulfonyl fluoride, $25 \mathrm{mM}$ dithiothreitol, and homogenized with PandaPLUS 2000 laboratory high-pressure homogenizer (GEA, Germany). Lysed bacteria were centrifuged at $21,200 \mathrm{~g}$ for 30 minutes at $4^{\circ} \mathrm{C}$. Pellets were solubilized in $10 \mathrm{mM}$ TRIS-HCl $\mathrm{pH}$ 8.0, $0.3 \mathrm{M} \mathrm{NaCl}, 8 \mathrm{M}$ urea, $0.5 \mathrm{mM}$ dithiothreitol, and $20 \mathrm{mM}$ imidazole for 30 minutes, followed by centrifugation at $21,200 \mathrm{~g}$ for 30 minutes at $4^{\circ} \mathrm{C}$. RGS8-His was purified from the supernatant by immobilized metal chelate affinity chromatography using Nickel Rapid Run resin (ABT, Spain) and ion-exchange chromatography (SP Sepharose Fast Flow, GE Healthcare, US), eluted in $50 \mathrm{mM}$ sodium phosphate $\mathrm{pH}$ 7.4, $8 \mathrm{M}$ urea, $1,000 \mathrm{mM} \mathrm{NaCl}$. Protein analysis was performed by SDS-PAGE using the NuPAGE system according to the manufacturer's manual (Invitrogen) and by mass spectrometry.

\section{Immunoblot and Line Blot}

RGS8-His in $50 \mathrm{mM}$ sodium phosphate $\mathrm{pH} 7.4,8 \mathrm{M}$ urea, $1,000 \mathrm{mM} \mathrm{NaCl}$ was incubated with NuPage lithium dodecyl sulfate sample buffer (Thermo Fisher Scientific, Schwerte, Germany) containing $25 \mathrm{mmol} / \mathrm{L}$ dithiothreitol at $70^{\circ} \mathrm{C}$ for 10 minutes, followed by SDS-PAGE (NuPAGE, Thermo Fisher Scientific, Schwerte, Germany). Separated proteins were 
A
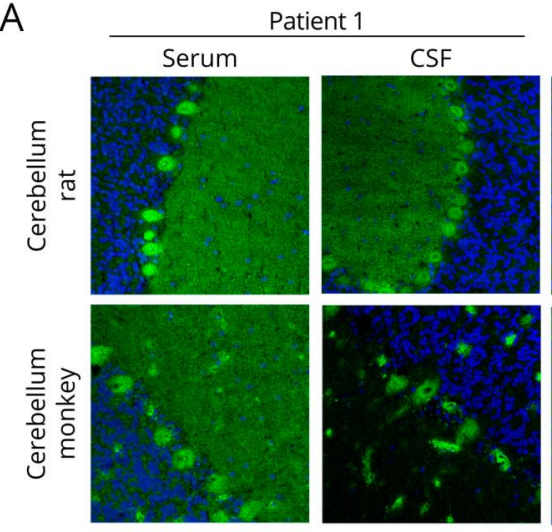

\section{B}

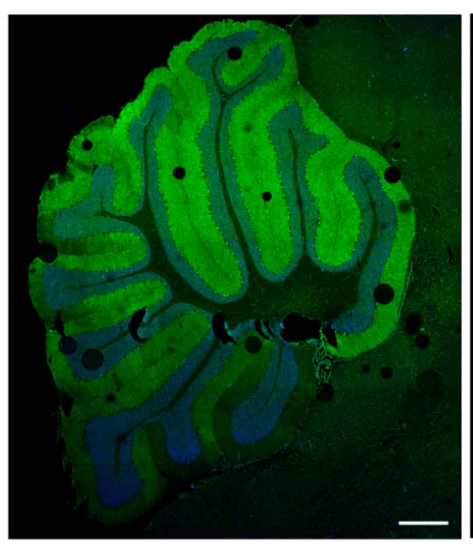

Patient 2
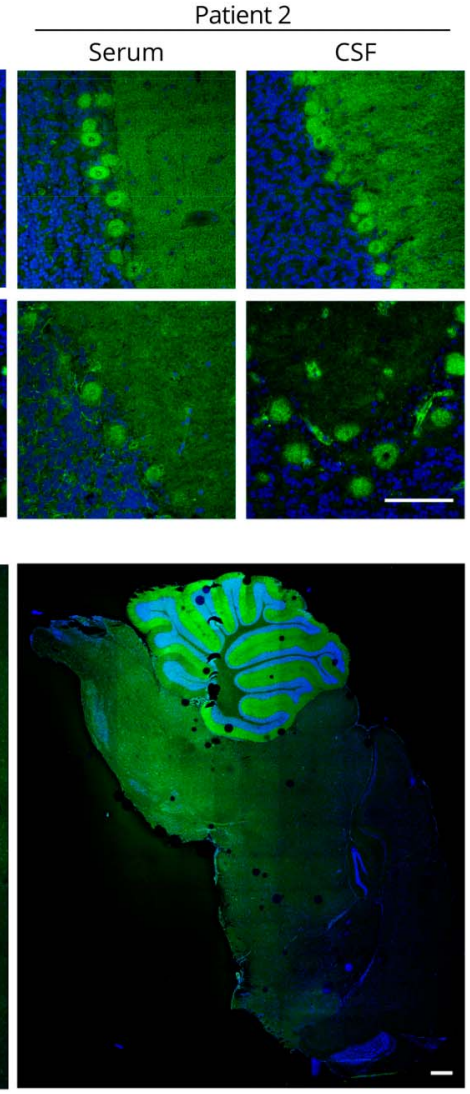

(A) Cerebellar cryosections were incubated with patient sera $(1: 32)$ or CSF $(1: 10)$ (green) in the first step and with Alexa488labeled goat anti-human IgG in the second step. Nuclei were counterstained by incubation with TO-PRO-3 iodide (blue). A fine-granular staining of cerebellar molecular layer and Purkinje cells was obtained with the strongest reaction on the Purkinje cells (scale bar $100 \mu \mathrm{m}$ ). (B) Sagittal sections of the murine whole brain were incubated with patient serum 2 (1:32) in the first step and with Alexa488-labeled goat antihuman IgG in the second step. Nuclei were counterstained by incubation with DAPI (blue). The patient serum mainly reacted with the cerebellum. No obvious reactivity against other parts of the brain was observed (scale bar $500 \mu \mathrm{m}$ ). electrotransferred onto a nitrocellulose membrane by tank blotting with transfer buffer (Thermo Fisher Scientific) according to the manufacturer's instructions. The membranes were blocked with Universal Blot Buffer plus (EUROIMMUN, Germany) for 15 minutes and incubated with the patient or control sera (dilution 1:200) in Universal Blot Buffer plus for 3 hours.

Alternatively, purified RGS8-His was coated as a line onto nitrocellulose membrane, and strips were incubated with sera (1: 100 dilution) in Sample buffer (EUROIMMUN, Germany) for 30 minutes. Serum incubation was followed by 3 washing steps with Wash buffer (EUROIMMUN, Germany), a second incubation for 30 minutes with alkaline phosphatase-labeled antihuman-IgG (1:10, EUROIMMUN, Germany), 3 washing steps, and staining with nitro blue tetrazolium/5-bromo-4-chloro-3indolyl-phosphate substrate (EUROIMMUN, Germany) for 10 minutes. After having dried, line strips were evaluated by the use of EUROLineScan software (EUROIMMUN, Germany). For the detection of anti-SOX1 reactivity, a SOX1 line blot (EUROIMMUN, Germany) was performed according to the manufacturer's instructions.

\section{ELISA}

Ninety-six-well plates (Nunc, Germany) were coated with $100 \mu \mathrm{L}$ of the recombinant protein $(5 \mu \mathrm{g} / \mathrm{mL})$ in PBS for 2 hours at $25^{\circ} \mathrm{C}$, washed 3 times with wash buffer $(0.05 \%$ [wt vol] Tween 20 in PBS), and then blocked with blocking buffer (0.1\% [wt/vol] casein in PBS) for 1 hour. Successful antigen immobilization was confirmed by incubation with a murine monoclonal anti-His tag antibody (1:2,000, Sigma-Aldrich, Germany). Serum and CSF samples were diluted 1:100 or 1: 10 in sample buffer (1\% [wt/vol] casein, $0.05 \%$ [wt/vol] Tween 20 in PBS) and incubated for 30 minutes, followed by 3 washing steps. By an incubation with anti-mouse IgG peroxidase (POD) conjugate (1:5,000, Jackson Research, United Kingdom) diluted $1 \times$ Taubert buffer (EUROIMMUN, Germany) or anti-human IgG POD (undiluted, EUROIMMUN, Germany) for 30 minutes, followed by 3 washing steps and incubation with tetramethyl benzidine (TMB) substrate (EUROIMMUN, Germany) for 15 minutes, bound antibodies were detected. For the determination of IgG subclasses, anti-human IgG1-POD, IgG2-POD, IgG3-POD, or IgG4-POD (9054-05, 9070-05, 9210-05, 9200-05 BIOZOL Diagnostica, Eching, Germany) diluted 1:1,000 in 1× Taubert buffer (EUROIMMUN, Germany) were used as secondary antibodies. All incubation steps were performed at room temperature. The optical density at $450 \mathrm{~nm}$ was read using an automated spectrophotometer (Tecan, Germany).

\section{Data Availability}

Anonymized data will be made available to qualified external researchers on the basis of scientific merit. 


\section{Results}

\section{Characterization of the Patients}

Clinical data were available for 2 of the patients.

\section{Patient 1}

A 53-year-old man reported a sudden onset of word retrieval difficulties and a dysfunction of fine motor skills of the right hand. Within 4 weeks, advancing unsteadiness in walking and increased slurring of speech were observed. Neurologic examination suggested a cerebellar syndrome with clear dysarthria, hypermetric saccades, ataxic gait and stand, minimal ataxia of the upper limbs, and significant ataxia of the lower limbs on both sides.

Brain MRI was normal and specifically showed no cerebellar or brainstem atrophy. Neurophysiologic examinations revealed no indication of additional polyneuropathy or nerve compression syndromes, except for bilateral carpal tunnel syndrome. Four weeks after disease onset, CSF analysis showed an intact blood-CSF barrier function, but chronic inflammatory changes characterized by lymphocytic pleocytosis $(8 / \mu \mathrm{L}$; normal $<5 / \mu \mathrm{L})$, slightly elevated protein level $(52.3 \mathrm{mg} / \mathrm{dL}$; normal $<45 \mathrm{mg} / \mathrm{dL})$, and CSF-specific oligoclonal bands. The analysis of serum and CSF for autoantibodies against known neuronal antigens was inconspicuous. However, in both serum and CSF, antibodies reacting with an unknown Purkinje cell antigen were recognized.

Searching for a tumor with CT scans of the thorax and abdomen, esophagogastroscopy, abdominal ultrasound, and colonoscopy did not reveal an underlying tumor. However, the patient had a severe gastric ulcer without sufficient immunohistochemical signs of malignancy at that time point. A laparoscopic gastric antrum resection 4 weeks later identified a highly malignant B-cell lymphoma of the gastric antrum.

Following tumor detection and assumption of paraneoplastic cerebellitis, IV immunoglobulin therapy (IVIG; $30 \mathrm{~g} / \mathrm{d}$ for 5 days) was applied, combined with $2 \times 50 \mathrm{mg}$ prednisolone/ day. A mild improvement of dysarthria and intentional tremor and a clear improvement of the gait ataxia were observed 4 days after starting the IVIG therapy. Afterward, medical conditions worsened again. After 10 weeks, the patient was treated again with a total of $120 \mathrm{~g}$ IVIG for 5 days. The tumor was treated with rituximab, cyclophosphamid, hydroxydaunomycin, oncovin, prednison (R-CHOP) chemotherapy (every 2 weeks) in parallel.

In a clinical follow-up, 4 years after onset of cerebellar syndromes, the patient reported clear improvement of general and neurologic conditions, although limb and gait ataxia persisted. The B-cell lymphoma has been successfully treated without relapse. Anti-Purkinje cell antibodies were no longer detectable in IFA with cerebellar tissues.

\section{Patient 2}

A 74-year-old woman presented with a rapidly progressive cerebellar syndrome. She reported increasing difficulties with gait, speech, posture, and upper limb coordination for about 8 weeks. Formally, she was still able to walk but a rolling walker was required. Neurologic examination showed a severe cerebellar syndrome with predominant dysarthria and ataxia of all limbs as well as substantial postural instability not only when attempting to walk but also when standing still and even while seated.

Brain MRI scans revealed rather light signs of a leukoaraiosis not affecting the brainstem as the only pathologic finding. Four months after diagnosis, a brain MRI scan indicated ongoing cerebellar atrophy (figure e-1, links.lww. com/NXI/A460). CSF showed a blood-brain barrier dysfunction with an elevated $\mathrm{IgG}$ index $\left(\mathrm{Q}_{\mathrm{ggG}} / \mathrm{Q}_{\text {albumin }}=\right.$ $11.25 / 10.7=1.05), 24.2 \%$ intrathecal synthesis and positive oligoclonal bands, but no signs of acute inflammation. There was no proof of any infectious disease. Further

Figure 2 Immunoprecipitation and Antigen Identification

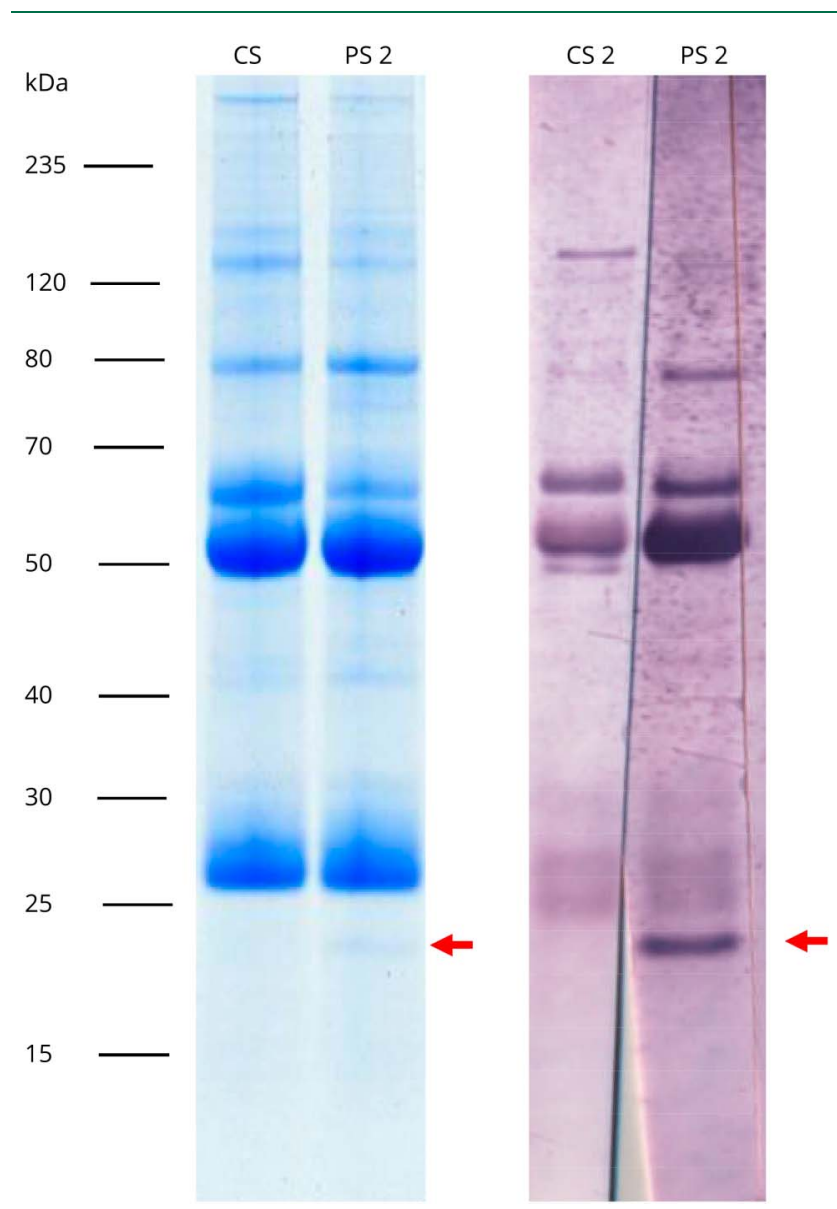

Lysates of the rat cerebellum were incubated with patient or control serum. Immunocomplexes were enriched with protein-G-coated magnetic beads, eluted by SDS, and subjected to SDS-PAGE analysis followed by staining with colloidal Coomassie (left) or immunoblot with patient or control serum (1: 200) (right). Arrows indicate the position of the immunoprecipitated antigen at about $25 \mathrm{kDa}$, which was identified as RGS8 by MALDI-TOF MS. 


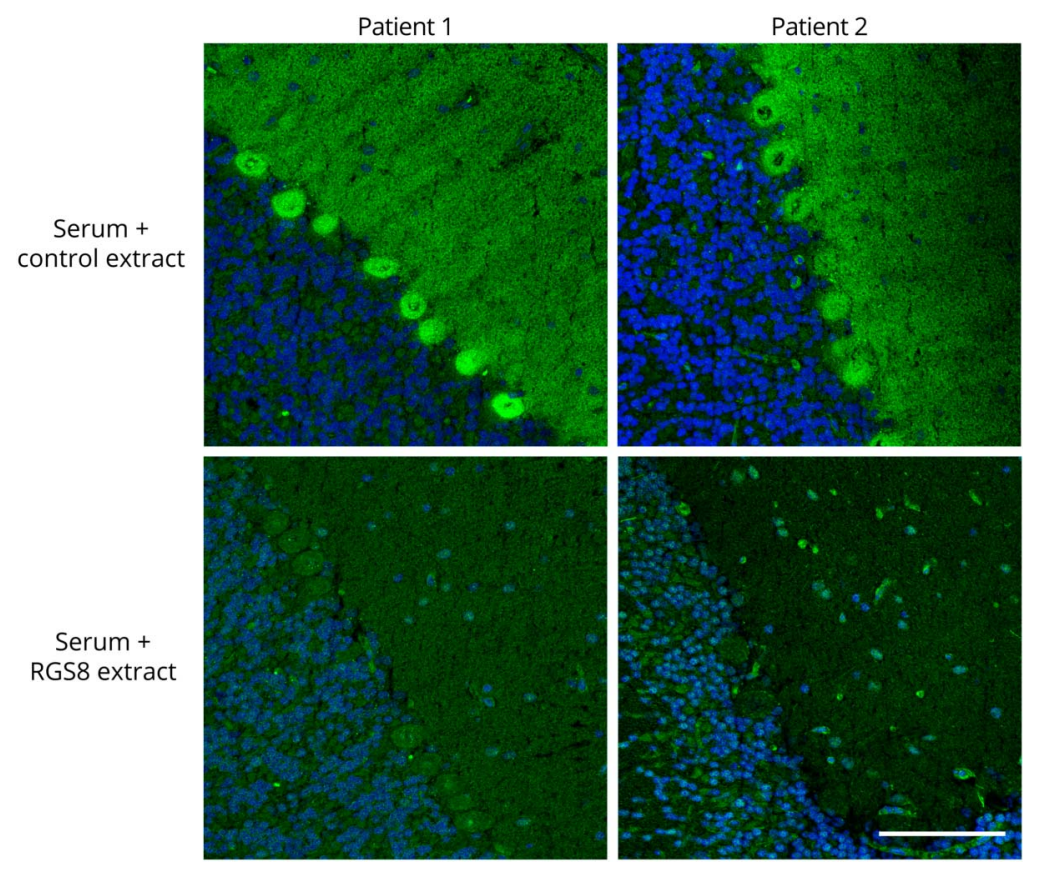

Patient sera (1:32, green) were preincubated with 1:10 diluted extracts of HEK293 cells transfected with RGS8 or with empty vector as control. The extract containing RGS8 abolished the immune reaction. Nuclei were counterstained by incubation with TO-PRO-3 iodide (blue) (scale bar $100 \mu \mathrm{m}$ ). physical examination revealed a prominent lymphadenopathy in the right axilla that was biopsied and delivered the diagnosis of Hodgkin disease (Ann Arbor IIA as after complete staging).
Initially, IV immunoglobulin therapy was applied (IVIG; $30 \mathrm{~g}$ over 5 days). In addition, the patient underwent 2 cycles of ABVD polychemotherapy, each in combination with $16 \mathrm{mg}$ dexamethasone/day followed by field radiation (up to $20 \mathrm{~Gy}$ )

Figure 4 Anti-RGS8 Autoantibody Detection in Patient Sera and CSF by Different Immunoassays

A

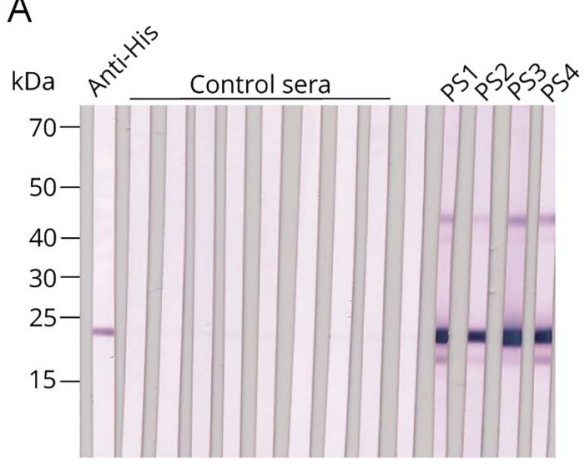

C

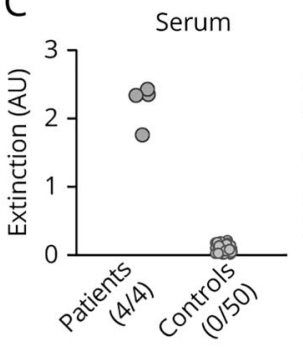

B

\begin{tabular}{|l|l|}
\hline Serum & $\begin{array}{l}\text { RGS8 } \\
\text { EUROLINE } \\
\text { intensity }\end{array}$ \\
\hline PS1 & 127 \\
\hline PS2 & 107 \\
\hline PS3 & 134 \\
\hline PS4 & 148 \\
\hline CS $(n=152)$ & Negative \\
\hline
\end{tabular}

$\mathrm{D}$

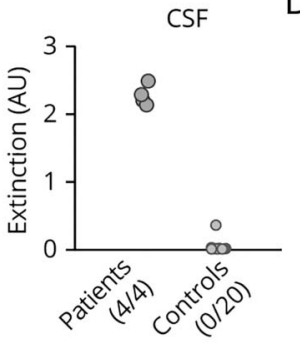

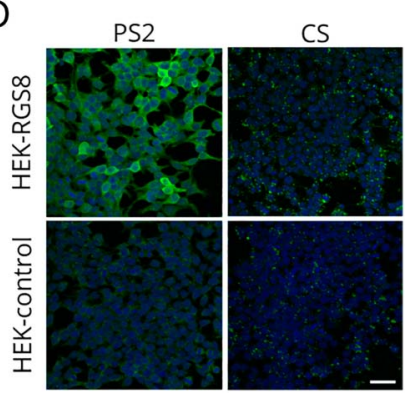

(A) Immunoblots with lysates of RGS8-transfected HEK293 cells incubated with 1:200 diluted patient or control sera and anti-human IgG-AP or anti-His antibody and anti-mouse IgGAP. (B) Results of RGS8 line blot assay with patient or control sera (CS) (1:100). (C) ELISA with purified recombinant RGS8His with patient or control sera $(1: 100)$ and patient or control CSF $(1: 10)$ and anti-human IgG POD. Positive and total numbers of sera and CSF are given below the diagrams. (D) IFA with patient or control sera (1:100) and RGS8- or Mocktransfected HEK293 cells incubated with anti-human IgGAlexa488. Nuclei were counterstained by incubation with TO-PRO-3 iodide (blue) (scale bar $50 \mu \mathrm{m}$ ). 
and finally reached complete remission of the tumor. The applied therapy resulted in some improvement of the cerebellar signs in the very beginning. However, 10 months after diagnosis, a noticeable progression of ataxic symptoms was observed. The patient could walk only a few fall-prone steps but was otherwise a wheelchair user. An immunoadsorption over 5 days could not achieve any major benefit. In the followup period, she has not recovered from the cerebellar syndrome despite tumor remission.

\section{Characterization of the Patients' Autoantibodies}

Sera and CSF of all 4 patients showed a similar staining of the Purkinje cells and the molecular layer on cryosections of cerebellum rat and monkey in indirect IFA (figure 1A and table e-1, links.lww.com/NXI/A462). On sagittal sections of the murine whole brain, a predominant reactivity of patients' autoantibodies against the cerebellum, excluding other parts of the brain, was observed (figure 1B). In further monospecific analyses with HEK293 cells overexpressing 30 recombinant neural autoantigens (Hu, Yo, Ri, CV2, PNMA2, ITPR1, Homer 3, CARP VIII, ARHGAP26, ZIC4, DNER/Tr, GAD65, GAD67, amphiphysin, recoverin, $\mathrm{GABA}_{\mathrm{B}}$ receptor, glycine receptor, DPPX, IgLON5, glutamate receptors [types NMDA, AMPA, mGluR1, mGluR5, and GLURD2], LGI1, CASPR2, AQP4 [M1 and M23], MOG, ATP1A3, and NCDN), the presence of a known neuronal autoantibody, which might have caused the observed cerebellar pattern, was excluded. In a line blot assay, weak anti-SOX1 reactivity was detected in patient serum 2 but not patient serum 1. However, SOX1 was not considered as the mayor target antigen of patient serum 2, as anti-SOX1 autoantibodies do not react with cerebellar Purkinje cells. ${ }^{12}$

\section{Identification of RGS8 as the Neuronal Target Antigen}

Immunoprecipitates obtained with the patient sera and homogenized rat cerebellum presented a $25-\mathrm{kDa}$ protein in Coomassie-stained gels, which was absent when normal control sera were incubated with the homogenates (figure 2). With the help of MALDI-TOF, the $25-\mathrm{kDa}$ protein fraction was identified as RGS8 from Rattus norvegicus (UNIPROT acc. \#P49804).

By preincubation with HEK293 lysate containing RGS8, the reaction of the patient sera with rat cerebellum could be abolished (figure 3), which can be considered a proof of correct antigen identification. Patients' autoantibodies were still reactive when they were preincubated with a similar extracted lysate of mock-transfected HEK293 cells. In contrast to this, the reactivity of anti-Yo, anti-DNER, or antiNCDN positive sera was not affected by preincubation with HEK293 RGS8 extract (figure e-2, links.lww.com/NXI/ A461). Furthermore, all patient sera showed a positive reaction in immunoblot or line blot assays with purified recombinant RGS8-His, which was not detected with healthy control sera $(\mathrm{n}=50$ for immunoblot, $\mathrm{n}=152$ for line blot) (figure 4, A and B). In addition, patient sera and CSF were analyzed by ELISA using purified RGS8-His (figure 4C). All analyzed patient sera and CSF were positive, whereas none of the control samples ( sera $n=50, \operatorname{CSF} n=20$ ) showed a reaction. In recombinant IFA (RC-IFA), positive reactions of patient sera were difficult to evaluate, as most of the RGS8transfected HEK293 cells showed only weak signals, indicating that this test system might not be suitable (figure 4D). Subclass analysis using the RGS8 ELISA revealed that all 4 patient sera contained IgG1 autoantibodies. In addition, in patient 4, IgG3 and IgG4 autoantibodies were detected.

Besides, 152 healthy control sera, 157 sera of patients with lymphoma (Hodgkin lymphoma $\mathrm{n}=24$ and non-Hodgkin lymphoma $\mathrm{n}=133$ ), and 193 sera of patients with other tumors (lung cancer $n=66$, cervical cancer $n=10$, breast cancer $n=83$, ovarian cancer $n=8$, and prostate cancer $n=26$ ) were analyzed by RGS8 line blot. None of these sera produced a similar immunofluorescence pattern as the patient sera on rat brain tissue, and all were negative on RGS8 line blots. Hence, we consider that IgG antibodies against RGS8 are not a general tumor marker, but might represent a marker for a subgroup of patients with cerebellar syndrome associated with lymphoma.

\section{Discussion}

Here, we report on 4 patients with high titers of IgG1 antibodies against RGS8 in serum and CSF. The 2 patients with clinical data available suffered both from a cerebellar syndrome associated with lymphoma. RGS8 antibodies were detected with multiple techniques, including immunoblot, line blot, ELISA, and RCIFA using recombinant RGS8 protein. We would suggest the line blot as preferred method to confirm anti-RGS8 antibody reactivity in patient samples with a characteristic pattern in IFA with cerebellar tissue sections.

RGS8 is an intracellular peripheral membrane protein, which is predominantly expressed in the brain, especially in the cell body and dendrites of cerebellar Purkinje cells. ${ }^{13,14}$ It belongs to a family consisting of over 30 members of signaling proteins, which regulate heterotrimeric G-proteins by stimulating the GTPase function of G-protein alpha subunits, converting them into their inactive guanosine diphosphate-bound state. ${ }^{15-17}$ RGS proteins are involved in the regulation of a variety of $\mathrm{CNS}$ actions, including synaptic plasticity, memory, and vision. ${ }^{18}$ For RGS8, functions in the regulation of neuronal excitability and neurite outgrowth have been proposed. ${ }^{16,19}$ In B lymphocytes, RGS proteins play a role in cell trafficking by regulation of Gprotein-coupled chemokine receptors signaling. ${ }^{20}$

The analysis of 157 sera of patients with lymphoma with the RGS8 line blot revealed no further anti-RGS8-positive patient sera. However, the frequency of PNS with lymphoma is very low, representing less than $1 \%$ of patients with tumor. ${ }^{5}$ In addition, none of the patients with lymphoma whose sera were examined showed the typical symptoms of a cerebellar syndrome.

Known autoantibodies associated with Hodgkin lymphoma target the cell surface antigens DNER (Tr), mGluR5 and 
mGluR1. ${ }^{6,8,9}$ Because these target antigens are not expressed by the tumor cells, the mechanism of autoantibody induction in patients with PNS with these autoantibodies is still unknown. ${ }^{5,7}$ The expression of RGS transcripts and proteins is dysregulated in different tumors. ${ }^{21-24}$ For example, RGS5 transcripts are markedly upregulated in 8 lymphoma subtypes, ${ }^{25}$ and RGS1 was shown to be overexpressed in most adult T-cell leukemia patients. ${ }^{22}$ RGS8 shares $52 \%$ sequence identity to RGS5 and RGS1, raising the possibility that common epitopes exist. Future studies are required to unravel RGS8 protein expression in lymphoma or other cancer types and to identify the epitopes recognized by anti-RGS8 autoantibodies. Furthermore, the prevalence of anti-RGS8 antibodies in patients with cerebellar syndrome and other neurologic disorders needs to be determined to further prove the specificity of this marker.

\section{Acknowledgment}

The authors thank Jonas Joneleit, Melanie König, Susann Satow, Jana-Melina Augener, and Laura Olejko (EUROIMMUN, Lübeck, Germany) for their excellent technical assistance and Anna-Lena Hickmann (EUROIMMUN, Lübeck, Germany) who edited the manuscript for nonintellectual content.

\section{Study Funding}

No targeted funding reported.

\section{Disclosure}

R. Miske and M. Scharf are employees of EUROIMMUN Medizinische Labordiagnostika AG, Luebeck, Germany. P. Stark, H. Dietzel, C. I. Bien, C. Borchers, and P. Kermer report no disclosures relevant to the manuscript. A. Ott, Y. Denno, and N. Rochow are employees of EUROIMMUN Medizinische Labordiagnostika AG, Luebeck, Germany. K. Borowski, C. Finke, and B. Teegen report no disclosures relevant to the manuscript. C. Probst and L. Komorowski are employees of EUROIMMUN Medizinische Labordiagnostika AG, Luebeck, Germany. Go to Neurology.org/NN for full disclosures.

\section{Publication History}

Received by Neurology: Neuroimmunology \& Neuroinflammation October 23, 2020. Accepted in final form February 18, 2021.

\section{Appendix Authors}

\begin{tabular}{lll}
\hline Name & Location & Contribution \\
\hline $\begin{array}{l}\text { Ramona } \\
\text { Miske, PhD }\end{array}$ & $\begin{array}{l}\text { EUROIMMUN AG, } \\
\text { Luebeck, Germany }\end{array}$ & $\begin{array}{l}\text { Study design and } \\
\text { conceptualization, major } \\
\text { role in the acquisition, } \\
\text { analysis and interpretation } \\
\text { of the data, and drafted the } \\
\text { manuscript }\end{array}$ \\
\hline $\begin{array}{l}\text { Madeleine } \\
\text { Scharf, PhD }\end{array}$ & EUROIMMUN AG, & $\begin{array}{l}\text { Major role in the } \\
\text { acquisition, analysis and } \\
\text { interpretation of the data, } \\
\text { and revised the manuscript } \\
\text { for intellectual content }\end{array}$ \\
& & formany
\end{tabular}

\section{Appendix (continued)}

\begin{tabular}{|c|c|c|}
\hline Name & Location & Contribution \\
\hline Patrick Stark & $\begin{array}{l}\text { Krankenhaus St. Elisabeth, } \\
\text { Damme, Germany }\end{array}$ & $\begin{array}{l}\text { Data collection and } \\
\text { analysis }\end{array}$ \\
\hline $\begin{array}{l}\text { Heiko } \\
\text { Dietzel, MD }\end{array}$ & $\begin{array}{l}\text { Krankenhaus St. Elisabeth, } \\
\text { Damme, Germany }\end{array}$ & $\begin{array}{l}\text { Data collection and } \\
\text { analysis }\end{array}$ \\
\hline $\begin{array}{l}\text { Corinna I. } \\
\text { Bien, MD }\end{array}$ & $\begin{array}{l}\text { Laboratory Krone, Bad } \\
\text { Salzuflen, Germany }\end{array}$ & $\begin{array}{l}\text { Data collection and } \\
\text { management and critical } \\
\text { revision and approval of } \\
\text { the final version of the } \\
\text { manuscript }\end{array}$ \\
\hline $\begin{array}{l}\text { Christian } \\
\text { Borchers, MD }\end{array}$ & $\begin{array}{l}\text { Nordwest-Krankenhaus } \\
\text { Sanderbusch, Sande, } \\
\text { Germany }\end{array}$ & $\begin{array}{l}\text { Data collection and } \\
\text { analysis }\end{array}$ \\
\hline $\begin{array}{l}\text { Pawel } \\
\text { Kermer, MD }\end{array}$ & $\begin{array}{l}\text { Nordwest-Krankenhaus } \\
\text { Sanderbusch, Sande, } \\
\text { Germany }\end{array}$ & $\begin{array}{l}\text { Data collection and } \\
\text { analysis and critical } \\
\text { revision and approval of } \\
\text { the final version of the } \\
\text { manuscript }\end{array}$ \\
\hline
\end{tabular}

\begin{tabular}{lll}
\hline $\begin{array}{l}\text { Anthonina } \\
\text { Ott }\end{array}$ & $\begin{array}{l}\text { EUROIMMUN AG, } \\
\text { Luebeck, Germany }\end{array}$ & $\begin{array}{l}\text { Data collection and analysis } \\
\text { and revised the manuscript } \\
\text { for intellectual content }\end{array}$ \\
\hline $\begin{array}{l}\text { Yvonne } \\
\text { Denno }\end{array}$ & $\begin{array}{l}\text { EUROIMMUN AG, } \\
\text { Luebeck, Germany }\end{array}$ & $\begin{array}{l}\text { Data collection and } \\
\text { analysis }\end{array}$ \\
\hline $\begin{array}{l}\text { Nadine } \\
\text { Rochow }\end{array}$ & $\begin{array}{l}\text { EUROIMMUN AG, } \\
\text { Luebeck, Germany }\end{array}$ & $\begin{array}{l}\text { Data collection and } \\
\text { analysis }\end{array}$ \\
\hline $\begin{array}{l}\text { Kathrin } \\
\text { Borowski }\end{array}$ & $\begin{array}{l}\text { Clinical Immunological } \\
\text { Laboratory Prof. Dr. med. }\end{array}$ & $\begin{array}{l}\text { Data collection and } \\
\text { analysis }\end{array}$ \\
& $\begin{array}{l}\text { Winfried Stöcker, Luebeck, } \\
\text { Germany }\end{array}$ &
\end{tabular}

\begin{tabular}{|c|c|c|}
\hline $\begin{array}{l}\text { Carsten } \\
\text { Finke, MD }\end{array}$ & Charité, Berlin, Germany & $\begin{array}{l}\text { Data collection and critical } \\
\text { revision and approval of } \\
\text { the final version of the } \\
\text { manuscript }\end{array}$ \\
\hline
\end{tabular}

\begin{tabular}{lll}
\hline $\begin{array}{l}\text { Bianca } \\
\text { Teegen, PhD }\end{array}$ & $\begin{array}{l}\text { Clinical Immunological } \\
\text { Laboratory Prof. Dr. med. } \\
\text { Winfried Stöcker, Luebeck, } \\
\text { Germany }\end{array}$ & $\begin{array}{l}\text { Data collection and } \\
\text { management and critical } \\
\text { revision and approval of } \\
\text { the final version of the } \\
\text { manuscript }\end{array}$ \\
$\begin{array}{l}\text { Christian } \\
\text { Probst, PhD }\end{array}$ & $\begin{array}{l}\text { EUROIMMUN AG, } \\
\text { Luebeck, Germany }\end{array}$ & $\begin{array}{l}\text { Data analysis and } \\
\text { management and critical } \\
\text { revision and approval of } \\
\text { the final version of the } \\
\text { manuscript }\end{array}$ \\
$\begin{array}{ll}\text { Lars } \\
\text { Komorowski, } \\
\text { PhD }\end{array}$ & $\begin{array}{l}\text { EUROIMMUN AG, } \\
\text { Luebeck, Germany }\end{array}$ & $\begin{array}{l}\text { Designed and } \\
\text { conceptualized the study } \\
\text { and critical revision and } \\
\text { approval of the final } \\
\text { version of the manuscript }\end{array}$ \\
& &
\end{tabular}

\section{References}

1. McKeon A. Paraneoplastic and other autoimmune disorders of the central nervous system. Neurohospitalist 2013;3:53-64.

2. Rosenfeld MR, Dalmau J. Paraneoplastic neurologic syndromes. Neurol Clin 2018; 36:675-685.

3. Albert ML, Darnell JC, Bender A, Francisco LM, Bhardwaj N, Darnell RB. Tumor-specific killer cells in paraneoplastic cerebellar degeneration. Nat Med 1998;4:1321-1324.

4. Darnell JC, Albert ML, Darnell RB. Cdr2, a target antigen of naturally occurring human tumor immunity, is widely expressed in gynecological tumors. Cancer Res 2000;60:2136-2139.

5. Graus F, Arino H, Dalmau J. Paraneoplastic neurological syndromes in Hodgkin and non-Hodgkin lymphomas. Blood 2014;123:3230-3238.

6. Bernal F, Shams'ili S, Rojas I, et al. Anti-Tr antibodies as markers of paraneoplastic cerebellar degeneration and Hodgkin's disease. Neurology 2003;60:230-234. 
7. de Graaff E, Maat P, Hulsenboom E, et al. Identification of delta/notch-like epidermal growth factor-related receptor as the $\mathrm{Tr}$ antigen in paraneoplastic cerebellar degeneration. Ann Neurol 2012;71:815-824.

8. Lancaster E, Martinez-Hernandez E, Titulaer MJ, et al. Antibodies to metabotropic glutamate receptor 5 in the Ophelia syndrome. Neurology 2011;77:1698-1701.

9. Sillevis Smitt P, Kinoshita A, De Leeuw B, et al. Paraneoplastic cerebellar ataxia due to autoantibodies against a glutamate receptor. N Engl J Med 2000;342:21-27.

10. Scharf M, Miske R, Kade S, et al. A spectrum of neural autoantigens, newly identified by histo-immunoprecipitation, mass spectrometry, and recombinant cell-based indirect immunofluorescence. Front Immunol 2018;9:1447.

11. Sitaru C, Dahnrich C, Probst C, et al. Enzyme-linked immunosorbent assay using multimers of the 16th non-collagenous domain of the BP180 antigen for sensitive and specific detection of pemphigoid autoantibodies. Exp Dermatol 2007;16: 770-777.

12. Sabater L, Titulaer M, Saiz A, Verschuuren J, Gure AO, Graus F. SOX1 antibodies are markers of paraneoplastic Lambert-Eaton myasthenic syndrome. Neurology 2008;70: 924-928.

13. Itoh M, Odagiri M, Abe H, Saitoh O. RGS8 protein is distributed in dendrites and cell body of cerebellar Purkinje cell. Biochem Biophys Res Commun 2001;287: 223-228.

14. Larminie C, Murdock P, Walhin JP, et al. Selective expression of regulators of G-protein signaling (RGS) in the human central nervous system. Brain Res Mol Brain Res 2004;122:24-34.

15. Hollinger S, Hepler JR. Cellular regulation of RGS proteins: modulators and integrators of G protein signaling. Pharmacol Rev 2002;54:527-559.
16. Saitoh O, Kubo Y, Miyatani Y, Asano T, Nakata H. RGS8 accelerates G-proteinmediated modulation of K+ currents. Nature 1997;390:525-529.

17. Siderovski DP, Willard FS. The GAPs, GEFs, and GDIs of heterotrimeric G-protein alpha subunits. Int J Biol Sci 2005;1:51-66.

18. Alqinyah M, Hooks SB. Regulating the regulators: epigenetic, transcriptional, and post-translational regulation of RGS proteins. Cell Signal 2018;42:77-87.

19. Lee J, Ghil S. Regulator of $\mathrm{G}$ protein signaling 8 inhibits protease-activated receptor $1 / \mathrm{Gi} / \mathrm{o}$ signaling by forming a distinct $\mathrm{G}$ protein-dependent complex in live cells. Cell Signal 2016;28:391-400.

20. Han JI, Huang NN, Kim DU, Kehrl JH. RGS1 and RGS13 mRNA silencing in a human B lymphoma line enhances responsiveness to chemoattractants and impairs desensitization. J Leukoc Biol 2006;79:1357-1368.

21. Xie $Y$, Wolff DW, Wei $T$, et al. Breast cancer migration and invasion depend on proteasome degradation of regulator of G-protein signaling 4. Cancer Res 2009;69:5743-5751.

22. Koga H, Imada K, Ueda M, Hishizawa M, Uchiyama T. Identification of differentially expressed molecules in adult T-cell leukemia cells proliferating in vivo. Cancer Sci 2004;95:411-417.

23. Koh J, Dar M, Untch BR, et al. Regulator of $\mathrm{G}$ protein signaling 5 is highly expressed in parathyroid tumors and inhibits signaling by the calcium-sensing receptor. Mol Endocrinol 2011;25:867-876.

24. Kim JH, Lee JY, Lee KT, et al. RGS16 and FosB underexpressed in pancreatic cancer with lymph node metastasis promote tumor progression. Tumour Biol 2010;31: 541-548.

25. Sethakorn N, Dulin NO. RGS expression in cancer: oncomining the cancer microarray data. J Recept Signal Transduct Res 2013;33:166-171. 


\title{
Neurology \\ Neuroimmunology \& Neuroinflammation
}

\author{
Autoantibodies Against the Purkinje Cell Protein RGS8 in Paraneoplastic Cerebellar \\ Syndrome \\ Ramona Miske, Madeleine Scharf, Patrick Stark, et al. \\ Neurol Neuroimmunol Neuroinflamm 2021;8; \\ DOI 10.1212/NXI.0000000000000987
}

This information is current as of March 29, 2021

\section{Updated Information \& \\ Services}

References

Subspecialty Collections

Permissions \& Licensing

Reprints including high resolution figures, can be found at:

http://nn.neurology.org/content/8/3/e987.full.html

This article cites 25 articles, 4 of which you can access for free at: http://nn.neurology.org/content/8/3/e987.full.html\#\#ref-list-1

This article, along with others on similar topics, appears in the following collection(s):

Autoimmune diseases

http://nn.neurology.org//cgi/collection/autoimmune_diseases

Class IV

http://nn.neurology.org//cgi/collection/class_iv

Gait disorders/ataxia

http://nn.neurology.org//cgi/collection/gait_disorders_ataxia

Paraneoplastic syndrome

http://nn.neurology.org//cgi/collection/paraneoplastic_syndrome

Information about reproducing this article in parts (figures,tables) or in its entirety can be found online at:

http://nn.neurology.org/misc/about.xhtml\#permissions

Information about ordering reprints can be found online:

http://nn.neurology.org/misc/addir.xhtml\#reprintsus

Neurol Neuroimmunol Neuroinflamm is an official journal of the American Academy of Neurology.

Published since April 2014, it is an open-access, online-only, continuous publication journal. Copyright

Copyright (C) 2021 The Author(s). Published by Wolters Kluwer Health, Inc. on behalf of the American

Academy of Neurology.. All rights reserved. Online ISSN: 2332-7812.

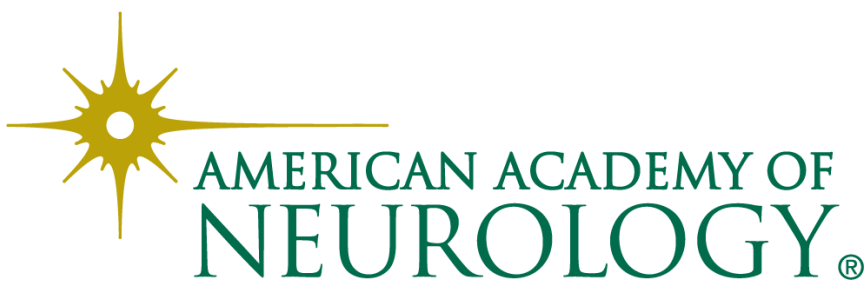

